\title{
Mungbean yellow mosaic virus-Vi Agroinfection by Codelivery of DNA A and DNA B From One Agrobacterium Strain
}

\author{
S. S. Jacob, R. Vanitharani, A. S. Karthikeyan, Y. Chinchore, P. Thillaichidambaram, and K. Veluthambi, \\ Department of Plant Biotechnology, School of Biotechnology, Madurai Kamaraj University, Madurai-625021, India
}

\begin{abstract}
Jacob, S. S., Vanitharani, R., Karthikeyan, A. S., Chinchore, Y., Thillaichidambaram, P., and Veluthambi, K. 2003. Mungbean yellow mosaic virus-Vi agroinfection by codelivery of DNA A and DNA B from one Agrobacterium strain. Plant Dis. 87:247-251.

Agroinfection of bipartite geminiviruses is routinely done by mixing two Agrobacterium strains that independently harbor partial tandem repeats of DNA A and DNA B. We report here an improved agroinfection method for bipartite geminiviruses that utilizes one strain of Agrobacterium that harbors DNA A and DNA B partial tandem repeats on two compatible replicons. A cointegrate vector, pGV2260::pGV1.3A, with the partial tandem repeat of Mungbean yellow mosaic virus-Vi (MYMV-Vi) DNA A and a binary vector, pGA1.9B, with the partial tandem repeat of MYMV-Vi DNA B gave an agroinfection efficiency of $24 \%$ when harbored in two Agrobacterium strains and an efficiency of $61 \%$ when harbored in one Agrobacterium strain. A combination of binary vectors, pGA1.9A with MYMV-Vi DNA A partial tandem repeat and pGA1.9B with DNA B partial tandem repeat, gave an agroinfection efficiency of $74 \%$ when harbored in two strains. But pGA1.9A and pPZP1.9B (a partial tandem repeat of DNA B), when present in the same Agrobacterium strain, gave 100\% agroinfection. Accumulation of viral DNA was shown by Southern blotting. The single-strain method using two compatible replicons consistently gave $100 \%$ agroinfection efficiency.
\end{abstract}

Additional keywords: blackgram, cotransformation, Vigna mungo

A geminivirus isolated and cloned from infected blackgram (Vigna mungo (L.) Hepper) plants (34) (EMBL Accession Numbers: VMYMV DNA A-AJ132575 and DNA B-AJ132574) has been named Mungbean yellow mosaic virus-Vi (MYMV-Vi; 12). The family Geminiviridae comprises viruses with circular, singlestranded DNA genomes. MYMV-Vi is classified under the genus Begomovirus and has a bipartite genome with DNA A and DNA B. Agroinfection is an effective method by which infectious viral clones are introduced into plants using Agrobacterium tumefaciens (14). A partial tandem repeat of a virus is constructed and placed in the T-DNA of a binary vector and introduced into A. tumefaciens. Upon inoculation of plants with the Agrobacterium strain and transfer of the T-DNA, the viral genome is released in the plant cells from the partial tandem repeat of the virus. Agroinfection with a geminivirus was first

Corresponding author: K. Veluthambi

E-mail: veluthambi@mrna.tn.nic.in

This research work was supported by funds from the Department of Biotechnology, Government of India and from the Indo-Swiss Collaboration in Biotechnology.

Accepted for publication 2 October 2002.

Publication no. D-2003-0106-01R

(C) 2003 The American Phytopathological Society reported for Tomato golden mosaic virus (TGMV; 29).

Two mechanisms have been proposed to explain the release of unit-length circular replicative forms in plants from the partial tandem repeats of geminiviruses delivered by agroinfection. In the absence of a duplication of viral origin of replication, homologous recombination between the tandem repeats leads to the release of unitlength double-stranded circles of DNA (27). Replicational release, a process in which the viral replication-associated protein replicates the full-length viral genome from the partial tandem repeat portion of the T-DNA, is favored when the viral replication origin is duplicated $(27,32)$. For agroinfection of bipartite geminiviruses, two strains of Agrobacterium are mixed and used for inoculation (coagroinoculation). The DNA A and DNA B partial tandem repeats are independently cloned in $\mathrm{Ti}$ plasmid-based vectors and mobilized into separate Agrobacterium strains $(3,10,11,13$, $22,23,28,35)$. The strains are grown individually, mixed, and used for agroinfection.

The feasibility of simultaneous delivery of DNA A and DNA B of a bipartite geminivirus (TGMV) from a single T-DNA in one Agrobacterium strain has been demonstrated (18). A similar approach was deployed recently for agroinfection of Ageratum yellow vein virus (AYVV; 30), where partial tandem repeats of DNA A and recDNA-A $\beta 17$ (a recombinant of DNA A and DNA $\beta$ ) and a tandem dimer of DNA $\beta$ were placed in one T-DNA of a binary vector. This approach increased the probability of delivering all three components to the same plant cell. Cloning of partial tandem repeats of both DNA A and DNA B in one T-DNA is a complex procedure. In addition, DNA A and DNA B need not be linked on the same T-DNA for the release of circular unit-length replicative forms inside the plant cell. Therefore, we tested a simple alternate approach of placing DNA $A$ and DNA B partial tandem repeats in the T-DNAs of two separate but compatible vectors that coexist in $A$. tumefaciens.

The efficiency of agroinfection is dependent on the Agrobacterium strain employed (2), the vir functions on the Ti plasmid (15), and the strength of promoters upstream of the viral replication-associated protein (24). We report that the efficiency of agroinfection with a bipartite geminivirus can be increased by using one Agrobacterium strain that harbors both DNA A and DNA B partial tandem repeats in compatible replicons. The single-strain method is simple to perform and more efficient than the two-strain method routinely used for agroinfection of bipartite geminiviruses.

\section{MATERIALS AND METHODS}

Construction of partial tandem repeat clones of MYMV-Vi. The plasmid pGA1.3A (19), harboring the partial tandem repeat of DNA A $(2.7-\mathrm{kb}$ PstI fragment representing the full-length 1-mer + a 0.74-kb PstI/BamHI fragment representing the 0.3-mer) of MYMV-Vi in the plasmid pGA472 (1), has a single viral origin of replication (Fig. 1a). It was digested with SacII and the partial tandem repeat was subcloned into the SacII site of pGV1500 (an intermediate vector that cointegrates into the Ti plasmid derivative pGV2260 by recombination in the $\mathrm{pBR} 322$ sequence present in both; 7) to produce $\mathrm{pGV} 1.3 \mathrm{~A}$ (Fig. 1b). A second partial tandem repeat clone of DNA A, pGA1.9A, harbors a 5.1$\mathrm{kb} S a c \mathrm{I} / \mathrm{X} h \mathrm{I}$ viral insert comprising a 2.7$\mathrm{kb}$ Pst I fragment representing the fulllength 1-mer and a 2.4-kb Pst $\mathrm{I} /$ HindIII fragment representing the $0.9-$ mer in pGA472 with RK2 replicon (Fig. 1c). The viral replication origin is duplicated in pGA1.9A.

The DNA B partial tandem repeat, a 5.1$\mathrm{kb} \mathrm{SacI/XhoI} \mathrm{fragment,} \mathrm{harbors} \mathrm{duplicated}$ viral replication origin in pGA1.9B (33). It 
includes a full-length (2.65-kb) DNA B with a $2.5-\mathrm{kb} 0.9$-mer (Fig. 1d). The plasmid pPZP1.9B (Fig. 1e) with pVS1 replicon was constructed as follows: the 5.1-kb DNA B partial tandem repeat was excised as a $\mathrm{SacI} / \mathrm{XhoI}$ fragment from pBS1.9B (33) and placed between the SacI/SalI sites of the binary vector, pPZP201 (16).

Mobilizations of partial tandem repeat clones of MYMV-Vi into A. tumefaciens. The partial tandem repeats in binary or cointegrate vectors were introduced into the respective Agrobacterium strains (Table 1) by triparental mating (9) or by electroporation. A. tumefaciens into which binary vectors were introduced by electroporation (transformants) or by triparental mating involving conjugation (transconjugants) were selected on $\mathrm{AB}$ minimal medium ( $\mathrm{pH}$ 7.0) (4) supplemented with the appropriate antibiotics (Table 1). All Agrobacterium transformants and transconju- gants were confirmed by Southern blot analysis for the presence of the partial tandem repeat clones (data not provided). For the construction of the cointegrate vector pGV2260::pGV1.3A, the intermediate plasmid pGV1.3A was introduced into C58C1 (pGV2260) by triparental mating. The recipient strain harbors pGV2260 (6), a derivative of an octopine type Ti plasmid, pTiB6S3, from which the T-DNA region has been deleted. The integration of pGV1.3A into pGV2260 will lead to the growth of Agrobacterium strains on a medium supplemented with carbenicillin, streptomycin, spectinomycin, and rifampicin (Table 1). The confirmation of cointegration, a process involving a recombination of pBR322 sequences of pGV2260 (6) and pGV1.3A, was performed by detailed restriction analysis with HindIII, KpnI, SalI, and EcoRI followed by Southern blot analysis (data not shown).
Agroinfection. The agroinfection procedure of Mandal et al. (23) was followed with a few modifications. Briefly, A. tumefaciens cultures were grown in $\mathrm{AB}$ minimal medium $(\mathrm{pH} 7.0)$ at $28^{\circ} \mathrm{C}$ to an optical density of 1 at $600 \mathrm{~nm}$. The cultures were centrifuged at $1,100 \times g$ for $10 \mathrm{~min}$ at $25^{\circ} \mathrm{C}$. The pellet was resuspended in $\mathrm{AB}$ minimal medium ( $\mathrm{pH}$ 5.6) supplemented with $100 \mu \mathrm{M}$ acetosyringone. In the case of the strains harboring only DNA A or DNA $\mathrm{B}$, equal volumes of the two corresponding cultures were mixed and used (coagroinoculation). V. mungo seeds germinated for $12 \mathrm{~h}$ were immersed in the respective cultures after the hypocotyl was punctured four times with a $30-\mathrm{G}$ needle. The infection was carried out at $25^{\circ} \mathrm{C}$ for $12 \mathrm{~h}$ in the dark. Subsequently, the seedlings were washed with sterile single distilled water and grown in sterile vermiculite wetted with half-strength Murashige-Skoog me-

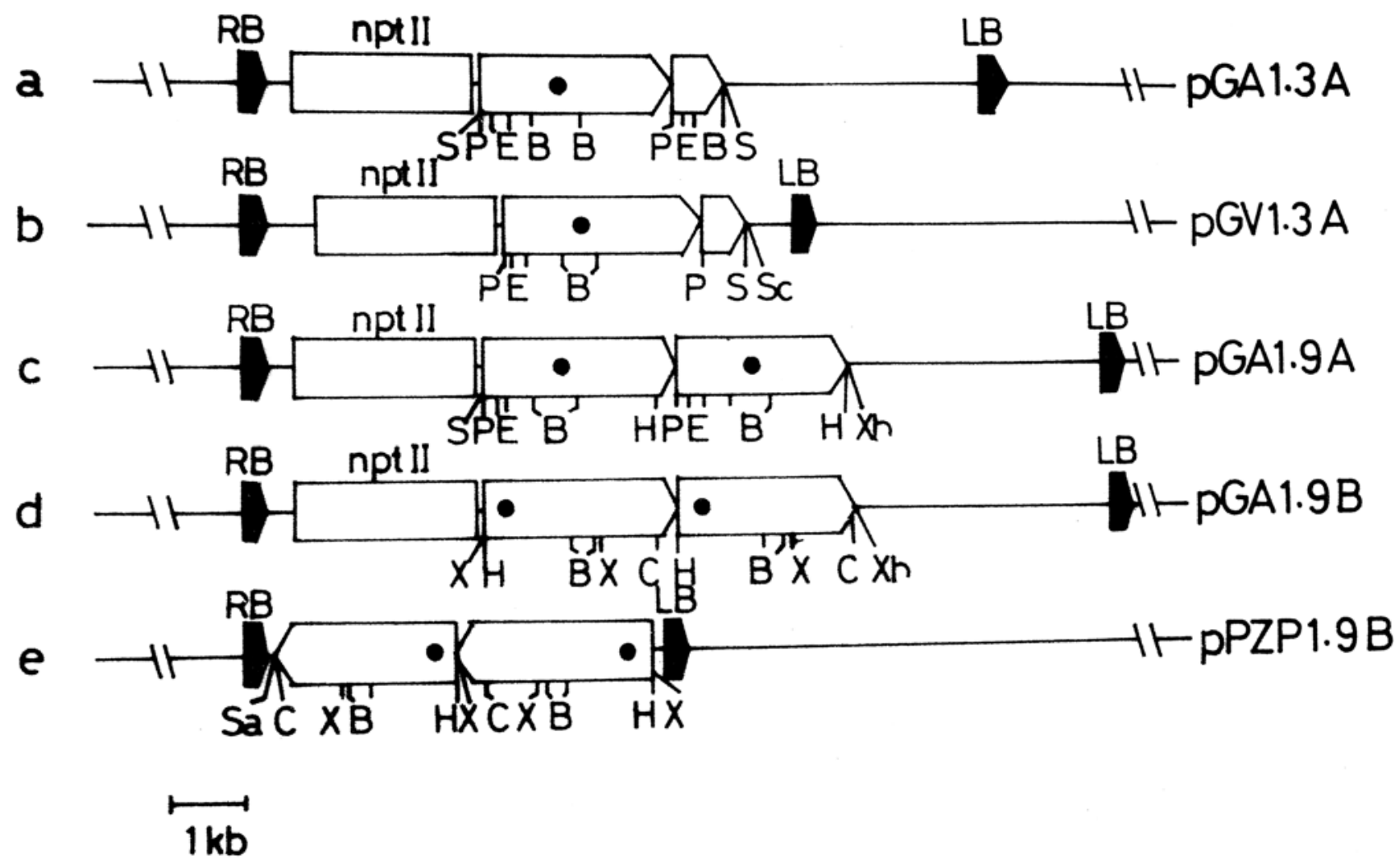

Fig. 1. Linear maps of Mungbean yellow mosaic virus-Vi (MYMV-Vi) partial tandem repeat regions of DNA A and DNA B. The full-length 1-mer portion and the 0.3-mer or 0.9-mer repeat portions of the virus are shown as boxed arrows; $\bullet=$ common region, RB $=$ right T-DNA border, LB $=$ left T-DNA border, $n p t \mathrm{II}=$ neomycin phospho-transferase II, B = BamHI, C = ClaI, E = EcoRI, H = HindIII, P = PstI, S = SacI, Sa = SalI, Sc = SacII, X = XbaI, and Xh = XhoI.

Table 1. List of Agrobacterium transconjugants and plasmids with partial tandem repeats harbored

\begin{tabular}{llll}
\hline $\begin{array}{l}\text { A. tumefaciens } \\
\text { recipient strains }\end{array}$ & $\begin{array}{l}\text { Reference } \\
\text { or source }\end{array}$ & $\begin{array}{c}\text { Mobilized } \\
\text { plasmids }\end{array}$ & \multicolumn{1}{c}{ Drugs used for transconjugant selection ( $\boldsymbol{\mu g} / \mathbf{m l})$} \\
\hline C58 & 31 & pGA1.9B & Rifampicin (10), Tetracycline (5). \\
C58 & 31 & pGA1.9A & Rifampicin (10), Tetracycline (5). \\
C58 & 31 & pGA1.3A & Rifampicin (10), Tetracycline (5). \\
Ach5 & 17 & pGA1.9A & Tetracycline (5). \\
Ach5 (pGA1.9A) & This study & pPZP1.9B & Tetracycline (5), Spectinomycin (100). \\
C58C1 (pGV2260) & 6 & pGV1.3A & Rifampicin (10), Carbenicillin (100), Streptomycin (300), Spectinomycin (100). \\
C58C1 & & & \\
(pGV2260::pGV1.3A) & This study & pGA1.9B & Rifampicin (10), Carbenicillin (100), Streptomycin (300), Spectinomycin (100), Tetracycline (5). \\
\hline
\end{tabular}


dium (25). The plants were placed in a growth room with a light and dark cycle of 16 and $8 \mathrm{~h}$, respectively, at $25^{\circ} \mathrm{C}$. After a period of 8 days, the plants were potted in a 1:1 mixture of sand and vermiculite and transferred to a greenhouse. Symptoms were scored based on the appearance of yellow mosaic pattern on the trifoliate leaves. The leaves with yellow mosaic symptoms were harvested 24 days after inoculation for DNA analysis.

DNA extraction and Southern analysis of agroinfected $V$. mungo plants. DNA was extracted from trifoliate leaves of control plants and symptomatic plants as previously described (26). DNA was estimated using Hoechst dye No. 33258 in a fluorometer. Total DNA $(3 \mu \mathrm{g})$ was fractionated in $1 \%$ agarose gels containing $1 \times$ TNE buffer $(40 \mathrm{mM}$ Tris, $20 \mathrm{mM}$ sodium acetate, and $2 \mathrm{mM}$ EDTA, $\mathrm{pH}$ adjusted to 7.5 with acetic acid), blotted onto ZetaProbe membrane (Bio-Rad Laboratories, Hercules, CA), and used for Southern analysis. For S1 nuclease treatment, $3 \mu \mathrm{g}$ of DNA was digested for $30 \mathrm{~min}$ at $37^{\circ} \mathrm{C}$ with 4.5 units of $\mathrm{S} 1$ nuclease. Probes were prepared with a random primer labeling kit (Amersham Pharmacia Biotech UK, Ltd., Buckinghamshire, UK) using $\left(\alpha-{ }^{32} \mathrm{P}\right) \mathrm{dCTP}$ (BRIT, Mumbai, India).

\section{RESULTS}

Single-strain method using a cointegrate vector. The cointegrate vector system offers a simple system to accommodate a compatible binary vector so that both DNA A and DNA B partial tandem repeat plasmids can be placed in the same Agrobacterium cell. A comparative analysis of agroinfection frequencies between the two-strain method and the single-strain method was first made using a cointegrate plasmid and a binary plasmid (Fig. 1). A mixture of A. tumefaciens strains C58 (pGV2260::pGV1.3A), harboring a cointegrate plasmid with DNA A, and C58 (pGA1.9B), harboring a binary plasmid with DNA B, caused 33 and $24 \%$ agroinfection in two independent experiments (Table 2). However, the use of a singlestrain method using C58C1 (pGV2260::pGV1.3A, pGA1.9B), harboring both DNA A and DNA B, resulted in the elevation of agroinfection frequency from 33 to $78 \%$ and from 24 to $61 \%$ in two independent experiments. Thus, deployment of a single Agrobacterium strain har- boring a cointegrate plasmid with DNA A partial tandem repeat and a binary plasmid with DNA B partial tandem repeat markedly increased the agroinfection frequency. Symptoms did not appear on control plants and on the plants infected with C58C1 (pGV2260::pGV1.3A) that carried DNA A alone. Symptoms appeared only when both DNA A and DNA B were used, confirming the bipartite nature of MYMV-Vi.

Single-strain method using two binary vectors. A comparison of agroinfection frequency of the single-strain and twostrain methods was made using binary vectors harboring both DNA A and DNA B partial tandem repeats. When the cultures of Ach5 (pGA1.9A) with DNA A and C58 (pGA1.9B) with DNA B were mixed and used in the two-strain method, agroinfection frequencies of 63 and $74 \%$ were obtained in two independent experiments (Table 2). However, in the single-strain method using Ach5 (pGA1.9A, pPZP1.9B), agroinfection frequency increased from 63 to $100 \%$ and from 74 to $100 \%$ in two independent experiments. The single-strain method using Ach5 (pGA1.9A, pPZP1.9B) consistently gave $100 \%$ agroinfection.
These results indicate that partial tandem repeats of DNA A and DNA B harbored on two binary vectors in a single Agrobacterium strain gave higher frequencies of agroinfection than when two strains are mixed and used in the conventional way.

Analysis of viral DNA in agroinfected V. mungo plants. DNA was extracted from representative agroinfected plants and subjected to Southern blot analysis to detect single-stranded and double-stranded MYMV-Vi DNA. Total DNA samples extracted from the trifoliate leaves of uninfected controls, plants infected with DNA A alone, and symptomatic trifoliate leaves infected with DNA A and DNA B were analyzed by Southern blotting. DNA Aand DNA B-specific probes (without the common region) were used to confirm the accumulation of the respective viral DNA in plants exhibiting yellow mosaic virus symptoms. S1 nuclease sensitivity of single-stranded DNA was used to distinguish between single-stranded virion DNA and double-stranded replicative forms.

Control plants (Figs. 2A and B and 3A and $\mathrm{B}$, lane $\mathrm{C}$ ) and plants infected with C58C1 (pGV2260::pGV1.3A) with DNA

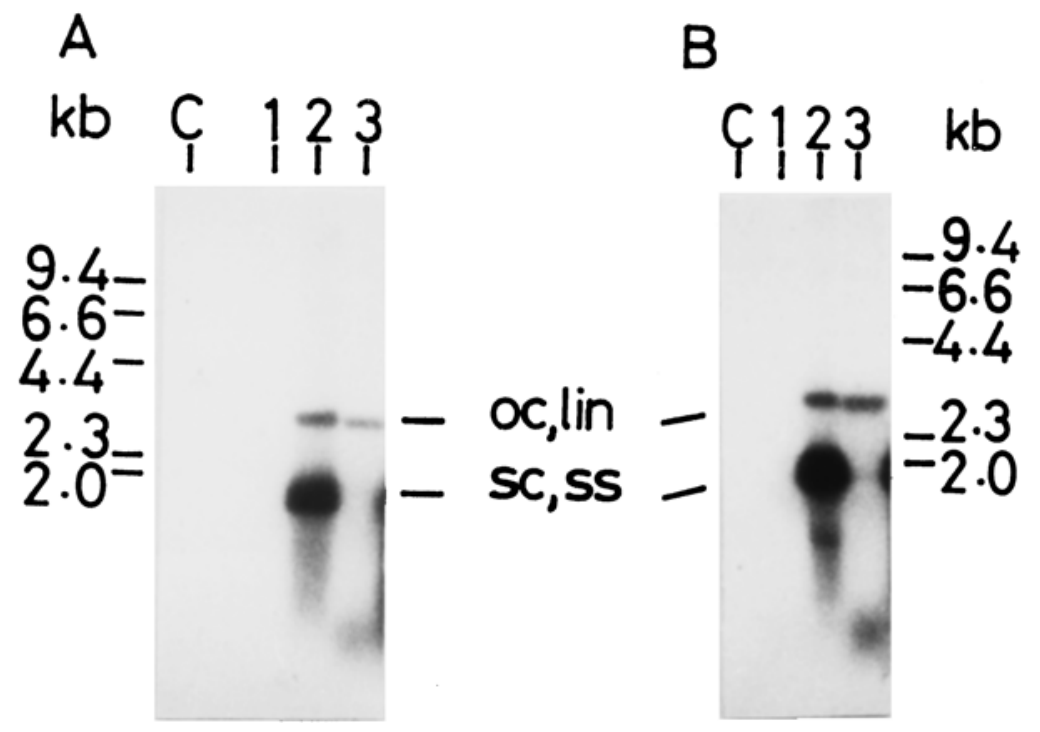

Fig. 2. Southern blot analysis of Vigna mungo agroinfected with cointegrate and binary vectors in the same Agrobacterium strain. A, DNA A-specific probe and B, DNA B-specific probe used were without common regions. Undigested total DNA ( $3 \mu \mathrm{g} / \mathrm{lane})$ was fractionated in $1 \%$ agarose gels with $1 \times$ TNE buffer ( $40 \mathrm{mM}$ Tris, $20 \mathrm{mM}$ sodium acetate, and $2 \mathrm{mM}$ EDTA, $\mathrm{pH}$ adjusted to 7.5 with acetic acid). DNA from control plants (lane C), plants inoculated with C58C1 (pGV2260::pGV1.3A) (lane 1), and plants inoculated with $\mathrm{C} 58 \mathrm{C} 1$ (pGV2260::pGV1.3A, pGA1.9B) (lanes 2 and 3) were analyzed. DNA was subjected to S1 nuclease treatment in lane 3; oc $=$ open circular, lin = linear, $\mathrm{ss}=$ single-stranded, $s c=$ supercoiled (20). Positions of $\lambda \backslash H$ HindIII fragments are marked.

Table 2. Comparison of Vigna mungo agroinfection efficiencies between single-strain and two-strain methods

\begin{tabular}{|c|c|c|c|}
\hline \multirow[b]{2}{*}{ Serial no. } & \multirow[b]{2}{*}{ Agrobacterium tumefaciens strains with partial tandem repeat clones } & \multicolumn{2}{|c|}{$\begin{array}{c}\text { Plants (\%) with yellow mosaic symptoms (sympto- } \\
\text { matic plants/total plants) }\end{array}$} \\
\hline & & Experiment I & Experiment II \\
\hline \multicolumn{4}{|c|}{ Two-strain method } \\
\hline 1 & C58 (pGV2260::pGV1.3A) + C58 (pGA1.9B) & $33(10 / 33)$ & $24(9 / 37)$ \\
\hline 2 & $\mathrm{Ach} 5(\mathrm{pGA} 1.9 \mathrm{~A})+\mathrm{C} 58(\mathrm{pGA} 1.9 \mathrm{~B})$ & $63(17 / 27)$ & $74(14 / 19)$ \\
\hline \multicolumn{4}{|c|}{ Single-strain method } \\
\hline 3 & C58C1 (pGV2260::pGV1.3A, pGA1.9B) & $78(35 / 45)$ & $61(26 / 43)$ \\
\hline 4 & Ach5 (pGA1.9A, pPZP1.9B) & $100(22 / 22)$ & $100(15 / 15)$ \\
\hline
\end{tabular}


A alone (Fig. 2A and B, lane 1) did not show any signal corresponding to the viral DNA using both the probes. Southern blot analysis of agroinfection experiments involving a combination of cointegrate vector with DNA A and a binary vector with DNA $B$ is presented in Figure 2. Plants infected by the single-strain method (C58C1 [pGV2260::pGV1.3A, pGA1.9B]), which exhibited yellow mosaic symptoms, showed the presence of viral DNA (lanes 2 and 3). Signals for both DNA A (Fig. 2A) and DNA B (Fig. 2B) were detected. An intense band at the $1.8-\mathrm{kb}$ position corresponds to the virion single-stranded DNA because it is not seen following S1 digestion. A weak 1.8-kb signal left after S1 nuclease digestion may represent the supercoiled replicative form (20). A band at the 2.7-kb position, remaining after $\mathrm{S} 1$ nuclease digestion, represents doublestranded replicative form in either open circular or linear form (20). V. mungo plants agroinfected by single-strain and two-strain methods involving two binary vectors with DNA A and DNA B also were subjected to Southern blot analysis (Fig. 3). Viral DNA corresponding to DNA A (Fig. 3A) and DNA B (Fig. 3B) was detected in all plants exhibiting yellow mosaic symptoms. An intense signal was seen at $1.8 \mathrm{~kb}$ for single-stranded virion DNA (plus supercoiled double-stranded replicative form). A signal at $2.7 \mathrm{~kb}$ corresponded to the linear and open circular forms of double-stranded replicative forms.

\section{DISCUSSION}

A simple strategy involving a single Agrobacterium strain harboring DNA A and DNA B partial tandem repeats in TDNAs of two compatible binary vectors yielded a high frequency $(100 \%)$ of agroinfection of the bipartite Begomovirus MYMV-Vi. Codelivery of DNA A from pGV2260::pGV1.3A (a cointegrate vector) and DNA B from pGA1.9B (a binary vector) in one Agrobacterium strain increased agroinfection from 33 to $78 \%$ and from 24 to $61 \%$ in two independent experiments (Table 2). Similarly, codelivery of DNA A from pGA1.9A (a binary vector) and DNA $\mathrm{B}$ from pPZP1.9B (a binary vector) increased agroinfection from 63 to $100 \%$ and from 74 to $100 \%$ in two independent experiments. In both cases, the single-strain strategy yielded higher agroinfection frequencies. The strategy of using compatible binary vectors to carry both DNA A and DNA B is advantageous over the strategy involving a cointegrate vector for DNA A, because the former yielded $100 \%$ agroinfection frequency consistently.

The relatively lower agroinfection efficiency of the cointegrate vector pGV2260::pGV1.3A could be due to two reasons: (i) the copy number of cointegrate vector in an Agrobacterium cell is one, whereas the binary vectors exist in multiple copies (5) and (ii) The 0.3-mer of the partial tandem repeat is relatively short in pGV1.3A and lacks the replication origin. We could not succeed in constructing cointegrate vectors harboring longer partial tandem repeats with the replication origin, because such plasmids exhibited extensive deletions of viral sequences when the intermediate plasmids were mobilized into Agrobacterium by triparental mating (data not shown). Agroinfection, involving repli-

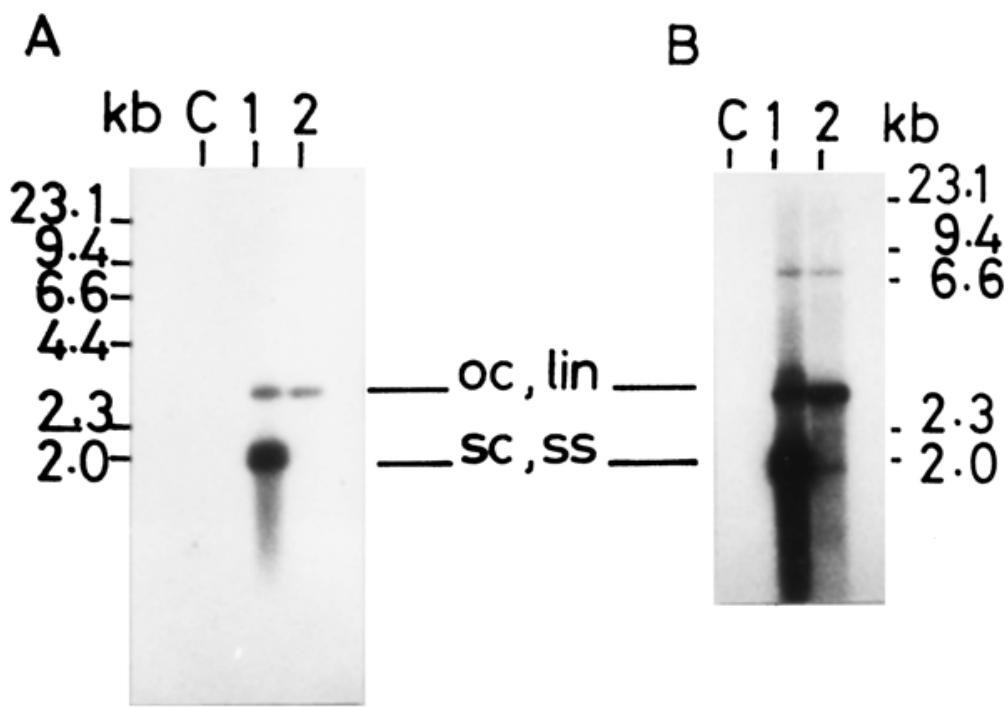

Fig. 3. Southern blot analysis of Vigna mungo agroinfected with two binary vectors in the same Agrobacterium strain. A, DNA A-specific probe and B, DNA B-specific probe without common regions were used. Undigested total DNA ( $3 \mu \mathrm{g} / \mathrm{lane})$ was fractionated in $1 \%$ agarose gels with $1 \times$ TNE buffer ( $40 \mathrm{mM}$ Tris, $20 \mathrm{mM}$ sodium acetate, and $2 \mathrm{mM}$ EDTA, pH adjusted to 7.5 with acetic acid). DNA from control plants (lane C), and plants inoculated with Ach5 (pGA1.9A, pPZP1.9B) (lanes 1 and 2) was analyzed. DNA was subjected to S1 nuclease treatment in lane 2; oc $=$ open circular, lin $=$ linear, $s s=$ single-stranded, $\mathrm{sc}=$ supercoiled. Positions of $\lambda \backslash H i n d I I I$ fragments are marked. 
into one Agrobacterium strain facilitates cotransfer of DNA A and DNA B from a single Agrobacterium strain. This modified approach resulted in $100 \%$ agroinfection. Besides the convenience of cloning and achieving a high frequency agroinfection, the single-strain strategy described here helps in performing studies with pseudorecombinants with a high efficiency of agroinfection.

\section{ACKNOWLEDGMENTS}

We thank S. B. Gelvin, Purdue University, for providing Agrobacterium strains; Plant Genetic Systems for pGV1500 and C58C1 (pGV2260); the National Pulses Research Center, Vamban, Tamil Nadu for V. mungo seeds; the Council of Scientific and Industrial Research, Government of India for Research Fellowships for A. S. Karthikeyan, R. Vanitha Rani, and S. S. Jacob; M. Thomas, S. Rani, and R. Sinha for technical help; R. Hemalatha for typing the manuscript; and K. Dharmalingam for permitting us to use the instruments in the Genetic Engineering Research Unit.

\section{LITERATURE CITED}

1. An, G., Watson, B. D., Stachel, S., Gordon, M. P., and Nester, E. W. 1985. New cloning vehicles for transformation of higher plants. EMBO J. 4:277-284

2. Boulton, M. I., Buchholz, W. G., Marks, M. S., Markham, P. G., and Davies, J. W. 1989. Specificity of Agrobacterium-mediated delivery of Maize streak virus DNA to members of the Gramineae. Plant Mol. Biol. 12:31-40.

3. Buragohain, A. K., Sung, Y. K., Coffin, R. S., and Coutts, R. H. A. 1994. The infectivity of dimeric potato yellow mosaic geminivirus clones in different hosts. J. Gen. Virol. 75:2857-2861.

4. Chilton, M.-D., Currier, T. C., Farrand, S. K., Bendich, A. J., Gordon, M. P., and Nester, E. W. 1974. Agrobacterium tumefaciens DNA and PS8 bacteriophage DNA not detected in crown gall tumors. Proc. Natl. Acad. Sci. USA 71:3672-3676.

5. Daley, M., Knauf, V. C., Summerfelt, K. R., and Turner, J. C. 1998. Co-transformation with one Agrobacterium tumefaciens strain containing two binary plasmids as a method for producing marker-free transgenic plants. Plant Cell Rep. 17:489-496.

6. Deblaere, R., Bytebier, B., Greve, H. De., Deboeck, F., Schell, J., Montagu, M. Van., and Leemans, J. 1985. Efficient octopine Ti plasmid-derived vectors for Agrobacteriummediated gene transfer to plants. Nucleic Acids Res. 13:4777-4788.

7. Deblaere, R., Reynaerts, A., Hofte, H., Hernalsteens, J.-P., Leemans, J., and Montagu, M. Van. 1987. Vectors for cloning in plant cells. Methods Enzymol. 153:277-292.

8. Depicker, A., Herman, L., Jacobs, A., Schell, J., and Montagu, M. Van. 1985. Frequencies of simultaneous transformation with different T-DNAs and their relevance to the Agrobacte- rium/plant cell interaction. Mol. Gen. Genet. 201:477-484

9. Ditta, G., Stanfield, S., Corbin, D., and Helinski, D. R. 1980. Broad host range DNA cloning system for Gram-negative bacteria: Construction of a gene bank of Rhizobium meliloti. Proc. Natl. Acad. Sci. USA 77:73477351.

10. Elmer, J. S., Sunter. G., Gardiner, W. E., Brand, L., Browning, C. K., Bisaro, D. M., and Rogers, S. G. 1988. Agrobacterium-mediated inoculation of plants with tomato golden mosaic virus DNAs. Plant Mol. Biol. 10:225234.

11. Evans, D., and Jeske, H. 1993. DNA B facilitates, but is not essential for, the spread of abutilon mosaic virus in agroinoculated $\mathrm{Nico}$ tiana benthamiana. Virology 194:752-757.

12. Fauquet, C. M., Maxwell, D. P., Gronenborn, B., and Stanley, J. 2000. Revised proposal for naming geminiviruses. Arch. Virol. 145:17431761.

13. Garrido-Ramirez, E. R., Sudarshana, M. R., and Gilbertson, D. 2000. Bean golden yellow mosaic virus from Chiapas, Mexico: Characterization, pseudorecombination with other bean-infecting geminiviruses and germ plasm screening. Phytopathology 90:1224-1232.

14. Grimsley, N., Hohn, B., Hohn, T., and Walden, R. 1986. "Agroinfection", an alternative route for viral infection of plants by using the Ti plasmid. Proc. Natl. Acad. Sci. USA 83:3282-3286.

15. Grimsley, N., Hohn, B., Ramos, C., Kado, C., and Rogowsky, P. 1989. DNA transfer from Agrobacterium to Zea mays or Brassica by agroinfection is dependent on bacterial virulence functions. Mol. Gen. Genet. 217:309316.

16. Hajdukiewicz, P., Svab, Z., and Maliga, P. 1994. The small, versatile $p P Z P$ family of Agrobacterium binary vectors for plant transformation. Plant Mol. Biol. 25:989-994.

17. Hamilton, R. H., and Fall, M. Z. 1971. The loss of tumor-initiating ability in Agrobacterium tumefaciens by incubation at high temperature. Experientia 27:229-230.

18. Hayes, R. J., Coutts, R. H. A., and Buck, K. W. 1988. Agroinfection of Nicotiana spp. with cloned DNA of tomato golden mosaic virus. J. Gen. Virol. 69:1487-1496.

19. Karthikeyan, A. S. 1998. Genetic transformation of Vigna mungo and characterization of Vigna mungo yellow mosaic virus. Ph.D. thesis, Madurai Kamaraj University, India.

20. Klinkenberg, F. A., and Stanley, J. 1990. Encapsidation and spread of African cassava mosaic virus DNA A in the absence of DNA B when agroinoculated to Nicotiana benthamiana. J. Gen. Virol. 71:1409-1412.

21. Komari, T., Hiei, Y., Saito, Y., Murai, N., and Kumashiro, T. 1996. Vectors carrying two separate T-DNAs for co-transformation of higher plants mediated by Agrobacterium tumefaciens and segregation of transformants free from selection markers. Plant J. 10:165174.

22. Lazarowitz, S. G., and Lazdins, I. B. 1991.
Infectivity and complete nucleotide sequence of the cloned genomic components of a bipartite squash leaf curl geminivirus with a broad host range phenotype. Virology 180:58-69.

23. Mandal, B., Varma, A., and Malathi, V. G. 1997. Systemic infection of Vigna mungo using the cloned DNAs of the blackgram isolate of mungbean yellow mosaic geminivirus through agroinoculation and transmission of the progeny virus by whiteflies. J. Phytopathol. 145:505-510.

24. Martin, D. P., and Rybicki, E. P. 2000. Improved efficiency of Zea mays agroinoculation with Maize streak virus. Plant Dis. 84:1096-1098.

25. Murashige, T., and Skoog, F. 1962. A revised medium for rapid growth and bioassays with tobacco tissue cultures. Physiol. Plant. 15:473-497.

26. Porebski, S., Bailey, L. G., and Baum, B. R. 1997. Modification of a CTAB DNA extraction protocol for plants containing high polysaccharide and polyphenol components. Plant Mol. Biol. Rep. 15:8-15.

27. Rigden, J. E., Dry, I. B., Krake, L. R., and Rezaian, M. A. 1996. Plant virus DNA replication processes in Agrobacterium: Insight into the origins of geminiviruses? Proc. Natl. Acad. Sci. USA 93:10280-10284.

28. Rochester, D. E., Kositratana, W., and Beachy, R. N. 1990. Systemic movement and symptom production following agroinoculation with a single DNA of tomato yellow leaf curl geminivirus (Thailand). Virology 178:520526.

29. Rogers, S. G., Bisaro, D. M., Horsch, R. B., Fraley, R. T., Hoffmann, N. L., Brand, L. Elmer, J. S., and Lloyd, A. M. 1986. Tomato golden mosaic virus A component DNA replicates autonomously in transgenic plants. Cell 45:593-600.

30. Saunders, K., Bedford, I. D., and Stanley, J. 2001. Pathogenicity of a natural recombinant associated with ageratum yellow vein disease: Implications for geminivirus evolution and disease aetiology. Virology 282:38-47.

31. Sciaky, D., Montoya, A. L., and Chilton, M.D. 1978. Fingerprints of Agrobacterium Ti plasmids. Plasmid 1:238-253.

32. Stenger, D. C., Revington, G. N., Stevenson, M. C., and Bisaro, D. M. 1991. Replicational release of geminivirus genomes from tandemly repeated copies: Evidence for rollingcircle replication of a plant viral DNA. Proc. Natl. Acad. Sci. USA 88:8029-8033.

33. Vanitha Rani, R. 2000. Analysis of DNA B of Vigna mungo yellow mosaic virus. Ph.D. thesis, Madurai Kamaraj University, India.

34. Vanitha Rani, R., Karthikeyan, A. S., Anuradha, S., and Veluthambi, K. 1996. Genome homologies among geminiviruses infecting Vigna, cassava, Acalypha, Croton and Vernonia. Current Sci. 70:63-69.

35. Zubiaur, Y. M., de Blas, C., Quinones, M Castellanos, C., Peralta, E. L., and Romero, J. 1998. Havana tomato virus, a new bipartite geminivirus infecting tomatoes in Cuba. Arch. Virol. 143:1757-1772. 